\title{
カラム実験
}

\author{
杉田 文*
}

\section{Laboratory column experiment}

\author{
Fumi SUGITA *
}

\section{1.はじめに}

野外で採取した土壤や砂をカラムに詰めて溶液 を通水するカラム実験は、単純で見た目にもわか りやすく、地中における水や物質の動きを手軽に 室内で再現することができる実験手法である。短 時間で行うことができるので、学部学生の教育目 的ばかりでなく、小学生への環境教育などにも活 用できる（Dunnivant and Olsen，2007）。一方、 目的を絞り注意深くおこなえば、精度のよい実験 結果をえることが可能なため、污染物質の輸送パ ラメータの同定や研究目的のために多くのカラム 実験が抗こなわれている。

一般的な一次元カラム実験装置の概要を図 1 に 示す。カラム実験装置は、カラム本体、充填する 土壤試料、通水する溶液やトレーサのほか、上下 流端に流量を制御する装置、および試料水を採 水・分析する機器からなる。本稿では主に 1 次元 を想定したカラム実験の手順を追いながら、筆者 が過去20年ほどの間に行ってきた 1 次元、 2 次 元、 3 次元のカラム/砂箱実験の経験から、カラ ム実験の持つ特徵や利点を生かし、よりよい精度 の実験を行うこうをまとめたい。当然のことなが ら実験はその目的により、最適な方法が異なる。 読者の方にはそれぞれの実験目的を勘案して実験 計画を組み立てる際の一助になれば幸いである。

\section{2. 実験装置}

\section{1 カラムの材質}

アクリル、塩化ビニル、ガラス、ステンレスな どがカラムの材質として用いられる。中でも透明 で内部を見ることができるアクリルが多く使われ る。アクリルは軽くて加工しやすく、カラム中に サンプリングポートなどをつけたい場合などにも むいている。しかし、中の砂の充填を頻繁に繰り 返す場合には表面に傷がついてすぐ曇ってしまう ため、ガラスの方が適している。現象の可視化の 必要がなく、カラムの重量が大きくなる大型カラ ムや、流す溶液やトレーサの特性によっては、よ り耐久性のすぐれているステンレスの方が適材で あることも多い。しかし、目で見ることにより得 られる情報は案外と多いので、ステンレスでも可 能であればのぞき空などを作っておくと便利であ る。

\section{2 カラムの形と大きさ}

広い野外を小さいカラム内で再現しようとする カラム実験ではカラム内の現象が側壁の影響を受 けないことが望ましい。側壁の影響を最小限にと どめる形状は円柱形とされる。四角柱のような角 のある形だと四隅に側壁の影響を受ける比較的広 い部分ができてしまうためである。 


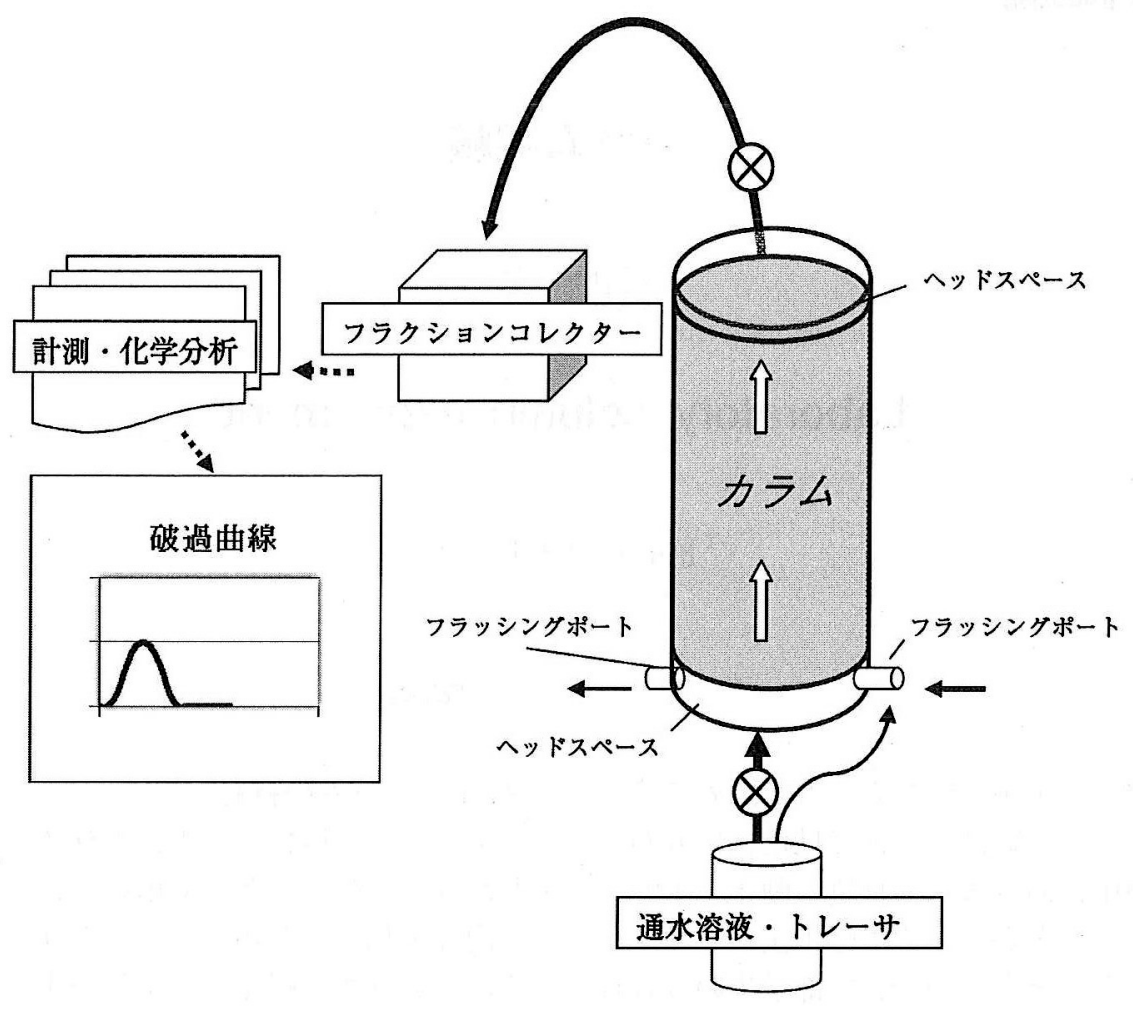

図1 カラム実験装置の概略

カラムの径は充填する粒子径の40倍以上がよい とされる (Relyea, 1982)。径が大きいほど全体 の流れに対する側壁の影響は相対的に小さくな る。一方、径が大きいと 1 次元実験の場合には流 れに垂直方向の断面において材質も流れも一様で 1 次元流とみなせるという条件を満たすことが難 しくなる。

一般的に水みちの形成やその影響を防ぐために カラム長はカラム径の 4 倍以上が良いとされる が、カラム断面方向の均質性さえ保たれればカラ ム径よりも短いカラム長でも十分に有用な実験が 可能である。カラム容積が小さい方が小回りが利 いて短時間に多種類の実験をおこなうことがで き、少ない労力でより多くの情報を手に入れるこ とができる。

2 次元の実験の場合には匹角柱が使い勝手がよ い形状であろう。この場合、観測刘象とする 2 次 元の面に対して垂直な方向において側壁の影響が 無視できる程度以上の厚みをもたせる必要があ る。ただし、この厚みが大きくなると、1 次元の
実験と同様、2 次元の実験でも仮定される厚み方 向における土壤や流れの均質性を保証することが 難しくなる。また、2 次元実験の場合、厚みを増 やすと急激に装置全体の重量が大きくなり、カラ ム実験の小回りの良さといった特典が失われる。 たとえば比較的小型の縦 $40 \mathrm{~cm}$ 、横 $50 \mathrm{~cm}$ 、厚さ $5 \mathrm{~cm}$ の 2 次元カラムに砂と水を詰めることを考 えると、砂と水だけで $19 \mathrm{~kg}$ 前後となりカラム本 体の重量を加えると $20 \mathrm{~kg}$ を超す。この厚みを 8 $\mathrm{cm}$ に増やすと $30 \mathrm{~kg}$ ほどになり、人が一人で移動 させるのも困難となり、土䗙の詰め替えも大作業 となってしまう。

改めて考えてみると円柱形のカラム内も実際に は 3 次元の世界である。したがって、円柱形のカ ラムで 3 次元の実験をおこなうことができる（た とえばWang ほか、1998など）。

カラム実験を計画する時には、側壁の影響が無 視できる大きさが必要である一方、時間的にも架 間的にも小回りの利くサイズが望ましいので、実 験者は両者の妥協点をみつけてカラムのサイズを 
決定することになる。

\section{3 カラムの充填}

乾いた砂やビーズの場合、カラムの中に丁寧に これらを詰めていけば簡単に短時間で均一に充填 することができる。均一にするために水中で充填 する手法がとられることが多いが、粒子の比重の 違いによってむしろ層状構造ができてしまうこと があり、注意が必要である。水中充填の場合には 粒子が浮かばない程度に水の量を徐々に増やし、 かつ、密度を確認しながら充填していくことが望 ましい。

不攪乱土壤の場合には側壁との接触面がスムー ズで水みちができていないことを確認する必要が ある。透明なカラムであれば目視により確認でき る。側壁と不攪乱土壤の間を人工的にシールする 場合には実験に化学的・物理的影響を与えないよ うな材質を選ばなければならない。

\section{4 カラムの上下端}

土壤を詰めたカラムの上下端をふさぐために、 細かい目の金属製のメッシュ、方紙（フィルター ペーパー)、ガーゼ、ガラスウール、ポーラスプ レートなどが用いられる。これらはできるだけ小 さい容積で、土壤の流出を防ぐ一方、溶液や空気 は抵抗なく通すものでなければならない。安価な ガーゼは溶液を材質内に吸収するので、精密な実 験には向かない。方紙は安価で容積も小さいが、 下流端では目詰まりに注意が必要なほか、メッ シュが細かすぎると方紙だけでも水の流れの抵抗 になることがある。また、種類によっては窒素な どを溶出するものもあるので、実験に使用する土 壤や溶質と照らして、販売されている多種多様な 方紙の中から慎重に選ばなければならない。ガラ スウールは、扱いにくいが溶質と反応を抗こしに くく、容積も小さく抑えられ、よい材質である。 ポーラスプレートも溶質と反応を执こしにくいが ほかの材質にくらべ大きめの容積となるかもしれ ない。

トレーサ試験のためには上流端のスペース内は トレーサ溶液とスムーズに置換出来る必要あり、 そのためのフラッシングポート（図 1) を溶液の 流入口とは別の 2 か所に加工してとりつけておく
と便利である。また、トレーサを導入して破過曲 線を得ることが目的の場合この上下端のヘッドス ペースはデッドゾーンとなり、実験誤差の元なの でできるだけ容積が小さい方がよい。上下端の蓋 のシールには市販のシール剂も十分利用できる が、何度も開閉を繰り返す場合には 0 リングが用 いられることが多い。Oリング上に小さな砂粒が のっていると確実なシールができないことがある のでパッキングの際には注意が必要である。

\section{5 周辺装置 $\cdot$ 機器}

電気伝導度やテンション測定のためのセンサー や採水装置をカラム内に設置するときには、水の 流れのさまたげにならないようにできるだけ小さ いものを互い違いに設置することが好ましい。カ ラムのサイズ、センサーの形状、土壌の特性など によるが、可能であれば土壤を充填した後でセン サーなどを挿入する方が土壤との接触の問題が少 ないようである。崩れやすい乾いた砂などの場合 はその限りでない。

溶液を一定の流量でカラムに送り込むには上下 端で圧力を調整するか、上流側で定量ポンプが用 いられる。定量ポンプは確実に流速を制御できて 便利であるが、従来型のポンプだと圧力が小さく 波打つこと（脈動）がさけられないので、実験の 求める精度やごく低流量のときには問題となるこ とがある。

流量やマスバランスを確認する意味でも下流端 で流出する溶液はすべて採取した方がよい。連続 で溶液を時間ごとに採取するためのフラクション コレクターはこの目的のためには便利である。

\section{3. 実験手順}

\section{1 空気抜き}

カラムに土壤を詰めて上下にふたを取り付ける と、いよい上実験開始となる。飽和実験の場合、 実験開始前に間隙中の空気または水を通水溶液で 置換するが、脱気した溶液をゆっくりと流すだけ では空気がカラム内に取り残されてしまう。二酸 化炭素のような水に溶けやすい気体で一度カラム 内の空気を置換したのち、溶液と入れ替えてしば らく放置するとカラム内の空気が溶液中にとけて 
残りにくい。二酸化炭素の場合、脱気水を導入し て浮いてくる気泡を $2-3$ 日放置すると目に見え る気泡は溶けて無くなる。

\section{2 トレーサの導入と流向}

実験から得られる破過曲線を数值解や解析解と 比較してパラメータを同定するような場合、境界 条件としてモデルに与えることができるトレーサ の形にできるだけ近い形でカラムにトレーサを導 入しなければならない。モデルの境界条件がパル スインプットや階段関数の場合、流入口でカラム 断面全体の溶液中のトレーサ濃度を瞬時に変化さ せる必要がある。そのためにはトレーサの導入前 に、カラム上流端のヘッドスペースと導入用 チューブ内の溶液をトレーサに入れ替えておかな ければならない。流出口を閉じてカラム内の水が 動かないようにしたのち、ヘッドスペースにとり つけたフラッシングポートを通じて導入用チュー ブとヘッドスペース内の溶液をトレーサと完全に 入れ替える。この作業はトレーサのカラム内への 分子拡散による流入を防ぐために、実験開始直前 にすばやく行わなければならならない。

パルスインプットの場合にはトレーサ導入のの ち、今度はバックグラウンド溶液をカラム断面方 向に素早く広げてシャープに濃度を下げなければ ならない。このためにはもう一度通水を止めて上 流側ヘッドスペースや導入チューブをバックグラ ウンド溶液に入れ替える作業を行う。実験の状況 によって通水を止めることができない場合には、 少ない容量の水でも断面方向に均等に素早く広が るように上流側のヘッドスペースに溶液の流入口 から広がる放射状の溝をつけておくと効果的であ る。

通常の地下水と溶存物質を想定した飽和実験の 場合、本来どのような方向にカラムを掞いてどの 方向に溶液を流しても結果に影響はないはずであ る。しかし、カラムを立てて下から上に向かって 通水するとカラム内にわずかに残っていた空気が 浮き上がってきたりするので、下から上に向かっ て流すとよい。

\section{3 カラム内からのサンプリング}

実験の途中でサンプリングポートよりカラム内
の溶液のみを抽出するときには、通水する溶液の 流束、総容量に比して採取する試水量が無視しう る十分に小さい容量になるように事前に計画する 必要がある。たとえば、通水する溶液量の $5 \%$ 以 下と決めたらおよその通水容量から採水総量を算 出してトレーサの動きを充分の捉えられるような サンプリングのポイントと時間間隔を計画するこ とになる。毎回のサンプリングでは、分析に必要 な容量のほか、サンプリングチューブ内の溶液も 置き換える必要があるのでその容量も考慮しなけ ればならない。できるだけカラムに近いところで サンプリングを㧍こなうとともに、トレーサの動 きをある程度正確に予測すると少ない採水量にお さえることができる。一方、濃度のピークを逃し たりテイリングを最後まで捉えられなかったりと いうことのないように、十分に安全ファクターを 乗じた時間と空間的範囲をもったサンプリングを 計画しなければならない。不飽和条件の場合で も、真空ポンプを使えば非常に低い水分量条件下 でもカラム内の土潩水をサンプルすることができ る。しかし、低水分のカラム内から採水すれば実 験そのものに影響が出ることは避けられない。

カラムを輪切りにして土壌と土壤水を同時にサ ンプルするときには、輪切りにする際に土壤が崩 れてしまうことが無いように注意が必要である。 本番で失敗してしまうとカラムの充填からすべて をやり直さなければならなくなってしまうので、 水分量の低い砂質の土䁃やビーズのような試料の 場合には、力のかけ具合や切る道具（ナイフや 糸）を変えて事前に何度か練習しておくとよい。

\section{4 再現性の確認}

長時間にわたってカラムに通水していると、水 みちが形成されたり化学反応などにより、実験条 件が知らない間に変わってしまうことがある。実 験の間カラム内の条件がずっと同じであったか確 認するために、実験の最後に一番初めに行った実 験と全く同じ実験を行うとよい。これにより、実

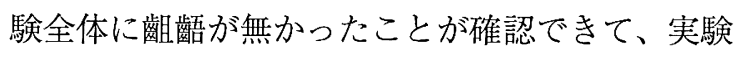
結果を安心して使うことができる。このような確 認により信頼性の高い実験ができることがカラム 実験の最大のメリットの一つである。 


\section{4. 実験結果の解釈}

典型的なカラム実験ではカラムの流出口で得ら れたトレーサ濃度変化を時間に対してプロット (破過曲線）したもの、あるいはカラム内の濃度 分布を距離に対してプロットしたものを結果とし て得る。污染物質回復の評価などで濃度や時間の 絶対值が重要であればそのままでよいが、他の実 験結果と比較したり、数值解や解析解と比較する 場合には各軸を無次元化しておくと便利である。 濃度は初期トレーサ濃度で、時間はポアボリュー ムで、距離はカラム長で実測值を無次元化するの が一般的である。

実験で得られた破過曲線や濃度分布曲線に種々 の解析解をあてはめて、輸送や反応のパラメータ を推定できるフリーのプログラム STANMOD (vesion 2. 2, Simunek, et al, 2004) がインター ネット上で提供されており、簡単に手に入れて走 らせることができる。これを用いると、モデルの 種類を選ぶことにより分散係数や遅延係数ばかり でなく、二重間隙構造や一部や全部の非平衡反応 を想定した各反応係数、生成・分解係数なども推 定できる。

実験結果として得られた濃度值は一般にグラフ 上に無限に小さい点（曲線）としてプロットされ るが、その点は有限の体積の試水からその平均值 として得られたデータであることを忘れてはなら ない。特に非常に精度のよい実験結果を解釈する ときは、得られるパラメータに影響を与えるの で、プロットするデータが時間方向、空間方向の どちらのどの区間の平均值であるか確認して確実 にプロットしなければならない。また、このこと はモデルで用いる境界条件の選択時にも注意が必 要である（Parker and van Genuchten, 1984）。

\section{5. カラム実験の利用とその限界}

実際の地下水中では水の流れと同時に化学反応 や物理的な拡散などが複雑に同時におきている。 実験条件を種々に設定した一連のカラム実験をお こなうことにより、実際の野外の土壤を使いなが ら、それら一つ一つのプロセスを分離して理解・ 解明することができる。また、私たちは地下でお
きている目で見ることができない現象を理論的に 理解できてもそれが本当に起きていると実感しに くい。そのような現象を目の前で再現して支配方 程式の中の一つ一つの項 (物理的プロセス・化学 的プロセス）やパラメータと照合することによ り、方程式と現象の結びつきが実感できることも カラム実験の利点の一つであると考えられる。透 明なカラムで目に見えるトレーサを用いればさら に効果的である。そのほか、パラメータ同定の目 的で行われる室内バッチ試験とくらべると、溶液 と土壤の比や接触時間が実際の野外のそれに近い という利点もある。

一方、室内に扔けるカラム実験装置は野外の帯 水層に比べてはるかにスケールが小さいため、大 スケールで生じる現象は再現できない。また、す べての数值モデリングがそうであるように、実験 から得られた結果は実験で設定した条件や仮定が 成立するとみなせる野外にのみ有效に適用できる。

\section{参考文献}

Dunnivant F.M. and R. Olsen (2007): A simple sand column laboratory exercise to illustrate pollutant hydrology in groundwater systems. Journal of Geoscience Education 55, 51-55.

Parker J.C. and M. Th. van Genuchten (1984): Flux-averaged and volume-averaged concentrations in continuum approaches to solute transport. Water Resources Research, 20, 7, 866-872.

Relyea J.F. (1982): Theoretical and experimental considerations for the use of the column method for determining retardation factors. Radioactive Wast Management and the Nuclear Fuel Cycle, 3, 151166.

Simunek, J., M. Th, van Genuchten, M. Sejna, N. Toride and FJ.Leij (2004): STANMOD (STudio of ANalytical MODels for solving convection-dispersion equation, ver2. 2).

Wang, Z., J. Feyen, M. Th, van Genuchten and D.R. Nielsen (1998): Air entrapment effects on infiltration rate and flow instability. Water Resources Research, 34, 2, 213-222.

（受付：2008年 6 月 6 日、受理：2008年 7 月 7 日） 